\title{
Analysis of Approaches for the Measurement of the Spatial Digital Divide in Russia and Abroad
}

\author{
Julia Lyshchikova \\ Department of Applied Economics and Economic Security \\ Belgorod State National Research University \\ Belgorod, Russia \\ lyshchikova@bsu.edu.ru \\ Elena Stryabkova \\ Department of Applied Economics and Economic Security \\ Belgorod State National Research University \\ Belgorod, Russia \\ stryabkova@bsu.edu.ru
}

\author{
Peter Likholob \\ Department of Information and Telecommunications Systems \\ and Technologies \\ Belgorod State National Research University \\ Belgorod, Russia \\ likholob@bsu.edu.ru \\ Igor Zaitsev \\ Department of Applied Informatics and Information \\ Technologies \\ Belgorod State National Research University \\ Belgorod, Russia \\ zaitsev_i@bsu.edu.ru
}

\begin{abstract}
Despite the increasing role and importance of digitalization at the present stage of development of the world economy, the problem of digital inequality is also worsening. From the point of view of sustainable spatial development of the economy, it is important to measure the digital inequality between cities and regions, urbanized and rural areas. This article is devoted to the study of approaches to the measurement of digital inequality at the national and regional level. The authors conducted a comparative analysis of the most wellknown national indexes of development of the digital economy, rating approaches to the assessment of the development of "smart cities", research methods of digitalization of the regions. The analysis of the Russian market of data processing centers in the context of regions and main players is carried out, the factors of its development are revealed. It is established that economic problems are concentrated in the absence of a business model for implementing smart city and smart region technologies in the constituent entities of the Russian Federation. Infrastructure problems, in turn, are associated with the phenomenon of digital inequality in Russian regions, low payback for IT-projects, and the lack of a single policy and a single driver for the implementation of the concepts under consideration. The main limitations and shortcomings of existing approaches to the measurement of spatial aspects of digital inequality are significant underestimation of the socioeconomic effects of digitalization at all levels, the lack of integrated methods of evaluation and ratings of digitalization of the regional level, the lack of estimates of intraregional digital inequality, which in the Russian economy is extremely important.
\end{abstract}

Keywords - smart city, smart region, digital inequality, spatial development, digital transformation, cyberspace, digital data, data processing center (DPC).

\section{INTRODUCTION}

The role and importance of digitalization at the current stage of development of the world economy is increasing every year. On the one hand, the digital economy is a driving force for innovation, competitiveness and economic growth in the world, creating new market opportunities, expanding the horizons for trade through e-commerce and participation in global production chains. On the other hand, the rapid development of the digital economy poses new threats and planetary risks related to digital challenges, cyber security issues, the impact on the environment and growing digital divide.

In most OECD (Organization for Economic Co-operation and Development) member countries digital economy accounts for about 4-7\% of GDP [1]. However, despite the significant development potential offered by the widespread use of information and communication technologies (ICT), it is not evenly realized: developing countries use it to a limited extent. The number of Internet users is increasing worldwide, however, the access to low-cost Internet remains limited for the least developed countries. According to the International Telecommunication Union, $81.3 \%$ of households in developed countries, $60.1 \%$ in CIS countries, $34.1 \%$ in developing countries and $6.7 \%$ in the least developed countries have access to the Internet.

The reason for this lies in the highly uneven development of ICT. In developing countries ICT infrastructure is not widely used, which is characterized by the concept of "digital divide". It is becoming increasingly complex and includes not only differences in the level of ICT infrastructure availability between developed and developing countries, but also within the national economy between households and companies, between different social groups, persons with high and low income, and between men and women (gender digital divide) [2]. From the point of view of sustainable spatial development of the national economy it is also important to study and measure the digital divide between cities and regions, urbanized and rural areas.

The issue of digital inequality has been the focus of research by scientists quite recently $[3 ; 4 ; 5 ; 6]$. In the article 
[7] digital inequality is considered as a problem of stratification of society in the possibility of receiving and processing information, the causes of digital inequality and ways to overcome it are analyzed.

The acceleration of the process of globalization and Informatization of the world economy and society allowed the world summit on the information society at the beginning of the 21 st century to proclaim the goal of the new millennium to build a global information society for all, in which everyone can create and use information and knowledge. But there are significant differences between countries in the development of information technology - the digital divide. The article [8] is devoted to the study of the current stage of building a global information society, methods for measuring the digital divide, its assessment, opportunities and prospects for developing countries in overcoming it.

The article [9] is devoted to the analysis of the relationship between the level of digitalization and several indicators of socio-economic development. The features of digital inequality in the modern global economy are revealed. The interrelationships between the level of digitalization development and indicators that characterize the level of competitiveness, investment, quality of life, and human development are revealed. It is concluded that in the context of the transition to a digital economy and the strengthening of global innovation hypercompetition, digital inequality between leading countries and underdeveloped countries is increasing.

Article [10] is devoted to the analysis of the problem of digital inequality between the current situation of Russia and the leading countries in the digital world in the context of the development of new information and communication technologies in Industry 4.0. The article clarifies the content of the categories "digital divide" and "digital inequality" and highlights the differences between them related to the technological, social, and economic dimensions of inequality in the modern digital space and due not only to the inclusion of subjects in digital technologies, but also to the intensity and effectiveness of their implementation and use in all spheres of activity and at all levels. The development of the digital economy and society leads to the fact that the infrastructure and technological digital divide manifests itself in an increasing number of dimensions in various spheres of life, as the well-being of society, social groups, and individuals increasingly depends on the ability to use information and communication technologies to access information and knowledge. The paper analyzes the indicators of digitalization in modern Russia based on data from international and domestic organizations and concludes that there is a digital gap between Russia and the leading countries in certain areas.

In [11] the essence and problems of interregional differences in the field of informatization are considered, and a comparative analysis of the poles of spatial Informatization is given: "growth points" - large cities and "white spots" settlements of the Russian hinterland. Spatial disparities in Informatization are identified as a special subject of the state policy of interregional alignment. The article describes the experience of evaluating and comparative analysis of interregional differences in the field of Informatization.

In the article [12] examines the features of digital inequality in Russian regions in the context of the introduction of innovative technologies in Industry 4.0. Analyzes the reasons that contribute to the formation of a digital gap between the subjects of the Russian Federation, assesses the level of development of regions based on the data of the Digital Russia index. Recommendations for overcoming the existing digital divide between Russian regions are presented.

\section{METHODS}

The aim of the study is to analyze and generalize approaches to measuring spatial digital inequality at the national and regional levels. The empirical basis of the study is the analytical reports and ratings published by the OECD, World Bank, World Economic Forum, International Telecommunication Union, European Commission, Pricewater house Coopers, Skolkovo and IKS-Consulting. We apply the comparative and content analysis of the best-known national indices of digital economy development, rating approaches to the assessment of the "smart cities" development, and methods of regional digitalization research.

\section{MAIN PART}

The measurement of the national digital divide level is most often carried out by means of building various types of complex indexes and subsequent rating of the subjects being evaluated both by individual components of the index and by its integral value.

For example, since 2002 the World Economic Forum has regularly published the results of the Networked Readiness Index, which measures the development of ICT in the world by 53 indicators grouped under three categories: the presence of conditions for ICT development, the readiness of society (citizens, business and government) to use ICT, and the level of ICT use in the public and commercial sectors (table 1).

TABLE I. NETWORKED READINESS INDEX LEADERS AND OUTSIDERS, 2016 (COMPILED BY THE AUTHORS USING THE DATA FROM [13])

\begin{tabular}{|l|l|l|l|l|l|}
\hline \multicolumn{3}{|c|}{ Leaders } & \multicolumn{3}{c|}{ Outsiders } \\
\hline Rank & Country & NRI & Rank & Country & NRI \\
\hline 1. & Singapore & 6.0 & 128. & Benin & 2.9 \\
\hline 2. & Finland & 6.0 & 129. & Eswatini & 2.9 \\
\hline 3. & Sweden & 5.8 & 130. & Liberia & 2.8 \\
\hline 4. & Norway & 5.8 & 131. & Nicaragua & 2.8 \\
\hline 5. & $\begin{array}{l}\text { United } \\
\text { States }\end{array}$ & 5.8 & 132. & Malawi & 2.7 \\
\hline 6. & Netherlands & 5.8 & 133. & Myanmar & 2.7 \\
\hline 7. & Switzerland & 5.8 & 134. & Guinea & 2.6 \\
\hline 8. & $\begin{array}{l}\text { United } \\
\text { Kingdom }\end{array}$ & 5.7 & 135. & Madagascar & 2.6 \\
\hline 9. & Luxembourg & 5.7 & 136. & Mauritania & 2.5 \\
\hline 10. & Japan & 5.6 & 137. & Haiti & 2.5 \\
\hline$\ldots$ & $\ldots$ & $\ldots$ & 138. & Burundi & 2.4 \\
\hline 41. & $\begin{array}{l}\text { Russian } \\
\text { Federation }\end{array}$ & 4.5 & 139. & Chad & 2.2 \\
\hline
\end{tabular}

The International Telecommunication Union (ITU) assesses the level of digitalization in the world by the ICT Development Index (IDI). The leader in the 2017 ranking was Iceland, followed by South Korea, Switzerland, Denmark, the United Kingdom; Russia ranked 45th (table 2). 
TABLE II. ICT DEVELOPMENT INDEX LEADERS AND OUTSIDERS, 2017 (COMPILED BY THE AUTHORS USING THE DATA FROM [14])

\begin{tabular}{|l|l|l|l|l|}
\hline $\begin{array}{l}\text { Rank } \\
\mathbf{2 0 1 7}\end{array}$ & Country & IDI 2017 & $\begin{array}{l}\text { Rank } \\
\mathbf{2 0 1 6}\end{array}$ & IDI 2016 \\
\hline 1. & Iceland & 8.98 & 2 & 8.78 \\
\hline 2. & Korea (Rep.) & 8.85 & 1 & 8.80 \\
\hline 3. & Switzerland & 8.74 & 4 & 8.66 \\
\hline 4. & Denmark & 8.71 & 3 & 8.68 \\
\hline 5. & United Kingdom & 8.65 & 5 & 8.53 \\
\hline 6. & Hong Kong, China & 8.61 & 6 & 8.47 \\
\hline 7. & Netherlands & 8.49 & 10 & 8.40 \\
\hline 8. & Norway & 8.47 & 7 & 8.45 \\
\hline 9. & Luxembourg & 8.47 & 9 & 8.40 \\
\hline 10. & Japan & 8.43 & 11 & 8.32 \\
\hline$\ldots$ & $\ldots$ & $\ldots$ & $\ldots$ & $\ldots$ \\
\hline 45. & Russian Federation & 7.07 & 43 & 6.91 \\
\hline$\ldots$ & $\ldots$ & $\ldots$ & $\ldots$ & $\ldots$ \\
\hline 170. & Ethiopia & 1.65 & 171 & 1.42 \\
\hline 171. & Congo (Dem. Rep.) & 1.55 & 170 & 1.48 \\
\hline 172. & Burundi & 1.48 & 172 & 1.39 \\
\hline 173. & Guinea-Bissau & 1.48 & 173 & 1.38 \\
\hline 174. & Chad & 1.27 & 174 & 1.06 \\
\hline 175. & Central African Rep. & 1.04 & 176 & 0.89 \\
\hline 176. & Eritrea & 0.96 & 175 & 0.96 \\
\hline
\end{tabular}

The European Commission annually measures and publishes the Digital Economy and Society Index (DESI) to assess the progress of European countries in moving towards a digital economy and society. The index consists of five specific indicators with different weights depending on their significance: Connectivity - 0.25; Human Capital - 0.25; Use of Internet - 0.15; Integration of Digital Technology - 0.2; Digital Public Services - 0.15 [15].

In 2018 the Russian state corporation Rosatom presented a pilot version of the National Digital Economy Development
Index for inter-country comparisons of the degree of readiness ( 7 evaluation blocks), use ( 5 evaluation blocks) and the impact (3 evaluation blocks) of digital technologies on socioeconomic development in a sample of 32 countries. More than 400 indicators were used in total [16]. For urban agglomerations the digital divide is measured primarily through a fairly large number of "smart city" rankings, including:

- 2017 rating of "smart cities" of the world by the Swedish IT-company EasyPark [17];

- "Smart City, Smart Strategy" report by European consulting company Roland Berger [18],

- rating of "smart cities" of the world according to the international consortium of researchers of urban smart technologies Intelligent Community Forum (ICF) [19],

- "The Smart City Playbook: smart, safe, sustainable" by Machina Research, a UK-based Internet of Things consulting firm [20]

- the rating of readiness of the world's largest cities and agglomerations for the introduction of future technologies "The future is coming: the city readiness index" by the Russian division of the consulting company PricewaterhouseCoopers [21].

Most of the "smart cities" ratings evaluate urban digital development in the main areas of ICT implementation in urban infrastructure: management, economics, ecology, mobility, urban development, social sphere (table 3).

TABLE III. TOP 10 “SMART CiTIES” (COMPILED BY THE AUTHORS USING THE DATA FROM [17], [18], [19], [20], [21])

\begin{tabular}{|c|c|c|c|c|c|}
\hline Rank & EasyPark & Roland Berger & ICF & Machina Research & PwC \\
\hline 1. & Copenhagen (Denmark) & Vienna (Austria) & $\begin{array}{ll}\begin{array}{l}\text { Chiayi } \\
\text { (Taiwan) }\end{array} & \text { City } \\
\end{array}$ & New York (USA) & $\begin{array}{l}\text { Singapore } \\
\text { (Singapore) }\end{array}$ \\
\hline 2. & Singapore (Singapore) & $\begin{array}{ll}\text { London } & \text { (United } \\
\text { Kingdom) } & \\
\end{array}$ & Edmonton (Canada) & Barcelona (Spain) & $\begin{array}{ll}\text { London } & \text { (United } \\
\text { Kingdom) } & \\
\end{array}$ \\
\hline 3. & Stockholm (Sweden) & St. Albert (Canada) & $\begin{array}{ll}\begin{array}{l}\text { Grey } \\
\text { (Canada) }\end{array} & \text { County } \\
\end{array}$ & San Francisco (USA) & Shanghai (China) \\
\hline 4. & Zurich (Switzerland) & Singapore (Singapore) & Ipswich (Australia) & $\begin{array}{l}\text { Mexico } \\
\text { (Mexico) }\end{array}$ & New York (USA) \\
\hline 5. & Boston (USA) & Chicago (USA) & $\begin{array}{l}\text { Melbourne } \\
\text { (Australia) }\end{array}$ & $\begin{array}{l}\text { Singapore } \\
\text { (Singapore) }\end{array}$ & Moscow (Russia) \\
\hline 6. & Tokyo (Japan) & Shanghai (China) & Moscow (Russia) & Paris (France) & Toronto (Canada) \\
\hline 7. & San Francisco (USA) & Birmingham (UK) & Taoyuan (Taiwan) & Cleveland (USA) & Tokyo (Japan) \\
\hline 8. & $\begin{array}{l}\text { Amsterdam } \\
\text { (Netherlands) }\end{array}$ & Chongqing (China) & - & Vienna (Austria) & Hong Kong \\
\hline 9. & Geneva (Switzerland) & Shenzhen (China) & - & Berlin (Germany) & Sydney (Australia) \\
\hline 10. & Melbourne (Australia) & Paris (France) & - & Shanghai (China) & Barcelona (Spain) \\
\hline
\end{tabular}

At the regional level, there are no common methods or international rankings of this kind. In Russian practice it is necessary to mention the "Smart Region" rating, which was first implemented in 2018 by the Internet magazine "Business Territory" [22] (table 4).

TABLE IV. RESUlTS OF THE "SMART REGION" RATING IN 2017 (COMPILED BY THE AUTHORS USING THE DATA OF [22])

\begin{tabular}{|l|l|c|c|c|c|c|c|}
\hline Rank & \multicolumn{1}{|c|}{ Region } & Total & $\begin{array}{c}\text { Smart } \\
\text { production }\end{array}$ & $\begin{array}{c}\text { Smart } \\
\text { agriculture }\end{array}$ & $\begin{array}{c}\text { Smart housing } \\
\text { and utilities }\end{array}$ & $\begin{array}{c}\text { Smart } \\
\text { city }\end{array}$ & $\begin{array}{c}\text { Smart } \\
\text { construction }\end{array}$ \\
\hline 1. & Kaluga Region & 22 & 5 & 5 & 4 & 4 & 4 \\
\hline 2. & Moscow Region & 21 & 5 & 4 & 4 & 4 & 4 \\
\hline 3. & Moscow & 19 & 5 & 0 & 5 & 5 & 4 \\
\hline 4. & Krasnodar Region & 19 & 4 & 5 & 4 & 3 & 3 \\
\hline
\end{tabular}




\begin{tabular}{|c|c|c|c|c|c|c|c|}
\hline 5. & Tatarstan & 19 & 5 & 4 & 4 & 4 & 2 \\
\hline$\ldots$ & $\ldots$ & $\ldots$ & $\ldots$ & $\ldots$ & $\ldots$ & $\ldots$ & $\ldots$ \\
\hline 81. & Adygeya & 3 & 0 & 1 & 1 & 1 & 0 \\
\hline 82. & Kalmykia & 3 & 0 & 0 & 1 & 2 & 0 \\
\hline 83. & Khakassia & 3 & 0 & 0 & 1 & 1 & 1 \\
\hline 84. & $\begin{array}{l}\text { The Jewish } \\
\text { Autonomous Oblast }\end{array}$ & 1 & 0 & 0 & 0 & 1 & 0 \\
\hline 85. & $\begin{array}{l}\text { Karachaevo- } \\
\text { Cherkessia }\end{array}$ & 1 & 0 & 0 & 0 & 1 & 0 \\
\hline
\end{tabular}

On a 100-point scale the range of Digital Russia index indicators in the first half of 2018 has narrowed and is between 37.2 and 75.14 points (in 2017 this range was 26.06-70.01). This result shows that the gap between the leading and closing regions has narrowed [23].

In addition, in 2018 "Digital Development" Fund announced the preparation of a complex national digitalization rating for the regions of the Russian Federation. The rating will assess consumer satisfaction with digitalization, the level of readiness for digitalization, and the dynamics of the digitalization process [24].

One of the indicators of the Federal project "Information infrastructure" in the framework of creating a global competitive infrastructure for data processing and storage based on domestic developments: $5 \%$ of the global volume of data storage and processing services by 2024 should be provided by Russian data processing centers (DPC) [25]. Today, there are 30 significant data center service providers in the Russian Federation. They own almost 90 sites (as of August 2020). Most of them are in Moscow - 58, and another 12 - in St. Petersburg. According to CNEWS [26], the number of racks at the largest Russian data center service providers increased by $10 \%$ in 2019 and is projected to increase by almost $20 \%$ in 2020 . The main indicators of the six largest data center service providers in Russia in 2020 are shown in table 5 .

TABLE V. CHARACTERISTICS OF THE LEADING PLAYERS IN THE RUSSIAN DATA CENTER MARKET [26]

\begin{tabular}{|c|c|c|c|c|c|}
\hline Company & $\begin{array}{l}\text { Number of } \\
\text { racks }\end{array}$ & $\begin{array}{l}\text { Area of } \\
\text { machine } \\
\text { rooms, } \mathbf{m}^{2}\end{array}$ & Power, МBт & $\begin{array}{l}\text { Number of } \\
\text { data centers }\end{array}$ & $\begin{array}{l}\text { Cities where data } \\
\text { centers are located }\end{array}$ \\
\hline Rostelecom & 11497 & 26225 & 149 & 27 &  \\
\hline IXcellerate & 3315 & 5500 & 26 & 2 & Moscow \\
\hline DataPro & 2400 & 3243 & 13,3 & 2 & Moscow \\
\hline MTS ("Avantage") & 2240 & 6400 & 20 & 1 & Moscow \\
\hline Linxdatacenter & 2020 & 4431 & 17 & 2 & $\begin{array}{ll}\text { Moscow, } & \text { Saint } \\
\text { Petersburg } & \\
\end{array}$ \\
\hline Selectel & 1889 & 8550 & 30 & 6 & $\begin{array}{lr}\text { Moscow, } & \text { Saint } \\
\text { Petersburg, Leningrad } \\
\text { region }\end{array}$ \\
\hline
\end{tabular}

According to the indicators in table 5, the data center market in the Russian Federation is increasingly showing trends in market concentration, including in the regional context. According to the international consulting agency IKS-Consulting, if in 2017 Moscow accounted for $68 \%$ of stand-up places, in $2020-72 \%$. The leader in data center services in the Russian Federation is Rostelecom, the only Russian provider of data center services that has a distributed network of federal and regional data centers in cities. As can be seen from table 5, Russian regions differ significantly in the number of data centers introduced and used. There is not only a lack of data centers, but also their uneven distribution across regions and Federal districts of the Russian Federation (table 6), which only worsens over time.
In 2017, all regions, except for Moscow and St. Petersburg, accounted for $18 \%$ of data center rack locations, and according to September 2020 - 15\%. This certainly hinders the digitalization of regions far from the capital, acts as a barrier to their development, and negatively affects the connectivity of the economic space.

In 2019, the Ministry of digital development, communications and mass media of the Russian Federation announced the start of developing a rating of attractiveness of Russian regions for the construction of data centers in the heat map format. The system is scheduled for launch in late 2020 [28]. 
TABLE VI. STRUCTURE OF COMMERCIAL DATA CENTER RACKS BY FEDERAL DISTRICTS OF THE RUSSIAN FEDERATION (EXCLUDING MOSCOW AND SAINT PETERSBURG) [27]

\begin{tabular}{|c|c|c|}
\hline No & Federal district & $\begin{array}{c}\text { Share of commercial } \\
\text { racks, \% }\end{array}$ \\
\hline 1. & $\begin{array}{ll}\begin{array}{l}\text { Central } \\
\text { district }\end{array} & \text { Federal } \\
\end{array}$ & 12 \\
\hline 2. & $\begin{array}{l}\text { North-Western } \\
\text { Federal district }\end{array}$ & 5 \\
\hline 3. & $\begin{array}{ll}\begin{array}{l}\text { Southern } \\
\text { district }\end{array} & \text { Federal } \\
\end{array}$ & 11 \\
\hline 4. & $\begin{array}{l}\text { North Caucasus } \\
\text { Federal district }\end{array}$ & 2 \\
\hline 5. & Volga Federal district & 36 \\
\hline 6. & Urals Federal district & 17 \\
\hline 7. & $\begin{array}{ll}\begin{array}{l}\text { Siberian } \\
\text { district }\end{array} & \text { Federal } \\
\end{array}$ & 15 \\
\hline 8. & $\begin{array}{ll}\begin{array}{l}\text { Eastern } \\
\text { district }\end{array} & \text { Federal } \\
\end{array}$ & 2 \\
\hline
\end{tabular}

JSC "ICS-holding" a leading publishing company in the ICT industry, devoted its next annual international conference to regional issues of data center development, which was held in September 2020 under the title "DPC. Region". Ilya Khala, CEO of 3data, presented the results of a study on the feasibility of investing in the development of a data center network in the Russian regions, commissioned by 3data international consulting Agency IKS-Consulting. The priority regions in the study are determined based on the analysis of such indicators as network availability, business activity, openness and the level of competition [29]. As a result, the rating was obtained, leading positions in which were taken by such regions as the Moscow region, Sverdlovsk region, Novosibirsk region, Tyumen region and the Republic of Tatarstan. Astrakhan region, Ivanovo region, Novgorod region, Tambov region, and the Republic of North OssetiaAlania became outsiders in the rating (table 7).

TABLE VII. RATING OF RUSSIAN REGIONS ON THE FEASIBILITY OF INVESTING IN DATA CENTER DEVELOPMENT [29]

\begin{tabular}{|c|c|c|}
\hline Rating leader & $\begin{array}{c}\text { Intermediate group (the resulting } \\
\text { index is higher than the median } \\
\text { value) }\end{array}$ & $\begin{array}{l}\text { Outsiders (the resulting index is } \\
\text { below the median value) }\end{array}$ \\
\hline $\begin{array}{l}\text { Moscow region, Sverdlovsk region, } \\
\text { Novosibirsk region, Tyumen region, } \\
\text { Republic of Tatarstan, Krasnodar territory, } \\
\text { Nizhny Novgorod region, Samara region, } \\
\text { Rostov region, Republic of Bashkortostan. }\end{array}$ & $\begin{array}{l}\text { Krasnoyarsk region, Chelyabinsk } \\
\text { region, Perm region, KhMAO, } \\
\text { Voronezh region, Stavropol region, } \\
\text { Belgorod region, Saratov region, Omsk } \\
\text { region, Irkutsk region, Volgograd } \\
\text { region, Primorsky Krai, Republic of } \\
\text { Udmurtia, Yaroslavl region, Orenburg } \\
\text { region. }\end{array}$ & $\begin{array}{l}\text { Kaliningrad region, Vladimir region, } \\
\text { Smolensk region, Tula region, } \\
\text { Khabarovsk region, Tomsk region, } \\
\text { Ulyanovsk region, Vologda region, } \\
\text { Tver region, Kaluga region, } \\
\text { Arkhangelsk region, Penza region, } \\
\text { Lipetsk region, Kirov region, Kursk } \\
\text { region, Bryansk region, Chuvash } \\
\text { Republic, Ryazan region, Murmansk } \\
\text { region, Ivanovo region, Tambov } \\
\text { region, Novgorod region, Republic of } \\
\text { North Ossetia-Alania, Astrakhan } \\
\text { region. }\end{array}$ \\
\hline
\end{tabular}

\section{CONCLUSION}

Summing up, it is necessary to note the main limitations and disadvantages of the considered approaches to spatial digital inequality assessment at the national, regional and urban levels:

- - significant underestimation of social and economic effects of digitalization at all levels (measurement of ICT implementation and use rather than results);

- lack of integrated assessment methods and digitalization ratings at the regional level; existing approaches are mainly based on the scaling up of "smart cities" assessment practices;

- - absence of intraregional digital divide assessments, which is very important in the context of Russian economy.

The economic problems of implementing the "smart city" and "smart region" concepts are mainly due to the lack of a clear business model. The problem is related to the fact that the recipient of "smart" services, as a rule, are residents of a city or region, while the operator is a commercial organization, and the payer is a subject (city, region, municipality). In this case, the implementation of the service is possible only if there is a high need for citizens, the subject has an economic opportunity to pay for the services of the service operator or its interest in the project. An example of such a service is the transport tracking service "Yandex.Transport". In this case, the city or regional structures provide the operator with access to public transport monitoring data, and the operator, in turn, processes them maintains statistics, builds forecasts, and packs them into a convenient form for the consumer - a mobile application, receiving in return various methods of monetization (advertising on maps, pop-up advertising, collecting user data and statistics, etc.).

Infrastructure problems that arise when implementing solutions for "smart" cities and regions are associated with several features at once. Utilities and telecommunications infrastructure, which has been developed for a long time, cannot always meet the needs of certain services in full. For example, to deploy a city and regional video surveillance system, you need to have several factors at once: power supply, transmission channels, and the ability to install equipment. At the same time, there is a question of payback of the created infrastructure. According to the now exMinister of digital development, communications and mass communications of the Russian Federation A. K. Volin, the 
three largest mobile operators in the Russian Federation have recouped their investments in the first and second generation networks ( $1 \mathrm{G}$ and $2 \mathrm{G}$ ), while the third and fourth generation networks have not yet paid off.

Another problem with the "smart city" and "smart region" concepts is the lack of a single policy and a single driver for their implementation. This problem is regularly discussed, including at the international industrial exhibition Innoprom, starting in 2017. The lack of a systematic approach in the future 10-15 years may lead to a situation where smart services for cities and regions will be built in the form of a "patchwork", i.e. by different operators, for different purposes, under different conditions and using different technologies. As a result, there is no possibility of mutual integration of services to achieve a synergistic effect in the interests of the city, region and the country.

Information technologies integrated into urban and regional digital ecosystems have not only several advantages, but also their negative features. One of them is exposure to cyber threats. Solving problems related to information security requires the involvement of qualified specialists, constant updating of software and hardware, and the use of specialized software and technical complexes. These measures to ensure information security can make up a significant part of the cost of implementing smart city and smart region services.

Despite these problems and the characteristics of the concept of "smart cities" and "smart regions", there are many examples of good services that are already running. One of them is the Active citizen project of the Moscow Government. The implementation of a simple idea - using information technology to make interaction between city authorities and residents more convenient and faster - allowed to involve about 2.295 million project participants. The result of the project is not only an increase in the efficiency of working with citizens 'appeals, but also a great social effect, including increasing the involvement of citizens in the decision-making process of the city government, increasing citizens' satisfaction with the work of city structures. Analogs of this service later appeared in many cities of the Russian Federation.

As another successful solution within the framework of the concept of "smart city" and "smart region", we can cite the automated outdoor lighting control system "Helios". According to the developers, the system is implemented in 21 subjects of the Russian Federation and allows you to organize automatic management of outdoor lighting facilities, monitoring of street lighting systems, and organizing energy consumption accounting. Even though as a result of the operation of this service, residents of cities and regions do not receive any information services, the service contributes to the organization of effective use of regional and city assets in ensuring the operability of outdoor lighting systems.

The problem of inequality in the development of digital infrastructure in the regions is obvious both for public authorities and for market players themselves, and both sides are trying to solve it. Stanislav Mirin, a leading consultant at IKS-Consulting, identified the following factors that determine the development potential of the regional data center market in the Russian Federation soon:

- data center construction initiatives from regional administrations and private investors;
- low penetration of colocation and cloud services in the regions;

- development of the state unified cloud platform (SUCP) as a role model;

- development of the EDGE data center concept;

- digitalization of business and everyday life and the resulting growth in data volume;

- development of communication networks and connectivity of regions [30].

Thus, despite the increase in investment interest in the growing regional data center market from both traditional and new market players (development companies, technology parks, industrial companies), the main factors for the development of digital infrastructure in the regions and, as a result, the increase in spatial connectivity, there is still a growing demand for data center services from businesses and government agencies, the achieved level of development of information and telecommunications technologies and personnel qualifications in the regions.

\section{ACKNOWLEDGMENT}

The article was prepared with the financial support of Grant of President of Russian Federation, project number MC-23.2019.6, the theme of the project ""Smart region" as an interdisciplinary concept for sustainable spatial development".

\section{REFERENCES}

[1] OECD 2017 OECD Digital Economy Outlook, OECD Publishing, Paris. URL: https://www.oecd.org/economy/oecd-digital-economyoutlook-2017-9789264276284-en.htm (accessed 02.10.2020).

[2] A. V. Abramova, MGIMO-University Bulletin, "The problem of "digital inequality" and the role of foreign aid in its solution, no.5, 2011, pp. 87-95.

[3] B.B. Acharya, "Conceptual evolution of the digital divide: a systematic review of the literature over a period of five years (2010-2015). World of Media”, Journal of Russian Media and Journalism Studies, no.7, 2017, pp. 41-74.

[4] H. Nieminen, "Digital divide and beyond: What do we know of information and communications technology's long-term social effects? Some uncomfortable questions", European Journal of Communication, no. 31(1), 2016, pp. 19-32. DOI: https://doi.org/10.1177/0267323115614198

[5] M. Ragnedda, H. Kreitem, "The three levels of digital divide in East E countries. World of Media", Journal of Russian Media and Journalism Studies, no. 4, 2018, pp. 5-27. DOI: 10.30547/worldofmedia.4.2018.1

[6] P. Attewell, "The first and second digital divides. Sociology of Education", no. 74(3), 2001, pp. 252-259.

[7] N. Beketov, "Information diversity and digital inequality in the development of Russia", Information resources of Russia, no. 5(111), 2009, pp. 27-31.

[8] I. N. Trofimova, "BRICS and rapidly developing countries on the way to the information society: ICT development and digital inequality", Questions about statistics, no. 10, 2013, pp. 41-53.

[9] S. A. Dyatlov, G. F. Feigin, "Digital inequality and economic development: features of country differentiation", Innovations, no. 10(240), 2018, pp. 48-54

[10] A. R., Safiullin, O. A., Moiseeva, "Digital inequality: Russia and the countries of the world in the conditions of the Fourth industrial revolution", Scientific and technical Bulletin of the Saint Petersburg state Polytechnic University. Economics, no. 12(6), 2019, pp. 26-37. 
[11] A. N. Shvetsov, "'Digital" inequality of Russian cities and regions: assessment methods and equalization policy" Problem analysis and state management design, no. 7(3), 2014, pp. 51-63.

[12] T. V. Aleksandrova, "Digital inequality of Russian regions: reasons, assessment, ways to overcome", Economics and business: theory and practice, no. 8, 2019, pp. 9-12.

[13] The Global Information Technology Report, 2016. URL: http://reports.weforum.org/global-information-technology-report2016/networked-readiness-index/ (accessed on: 02.10.2020).

[14] ICT Development Index IDI. URL: http://www.itu.int/net4/ITUD/idi/2017/index.html (accessed 02.10.2020).

[15] Europe's Digital Progress Report for 2018, European Commission. URL: https://ec.europa.eu/digital-single-market/en/desi (accessed 02.10.2020).

[16] National Digital Economy Development Index, Pilot implementation.

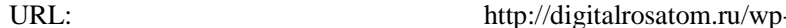
content/uploads/2019/01/Индекс_развития_ЦЭ.pdf （accessed 02.10.2020).

[17] Smart City Index 2017. URL: https://www.easyparkgroup.com/smartcities-index/ (accessed 11.08.2020).

[18] The Smart City Breakaway. URL: https://www.rolandberger.com/publications/publication_pdf/roland_b erger_smart_city_breakaway_1.pdf (accessed 11.08.2020).

[19] Intelligent Community Forum (ICF). URL: https://www.intelligentcommunity.org/icf_names_the_top7_intelligen t_communities_of_2017 (accessed 02.10.2020).

[20] The Smart City Playbook: smart, safe, sustainable. URL: https://www.itu.int/en/ITU-D/Regional-

Presence/AsiaPacific/Documents/Events/2017/Sep-

SCEG2017/SESSION-3_Nokia_Mr_Guillaume_Mascot.pdf (accessed 02.10.2020).

[21] The future is coming: the city readiness index. A pre-release. URL: http://d-russia.ru/wp-content/uploads/2017/07/the-future-is-comingrus.pdf (accessed 02.10.2020).

[22] Smart Region Rating, 2017, Business Territory. URL: http://www.bizter.ru/articles/\&art_id=1175 (accessed on: 02.10.2020).

[23] Digital Russia Index. URL: https://finance.skolkovo.ru/ru/sfice/research-reports/1779-2018-1015/ (accessed 02.10.2020).

[24] V.I. Blanutsa, "Territorial structure of the Russian digital economy: preliminary delimitation of smart urban agglomerations and regions", Regional Research of Russia, no. 9(4), 2019, pp. 318-328.

[25] National project "Digital Economy of the Russian Federation". URL: https://digital.gov.ru/ru/activity/directions/858/ (accessed 02.10.2020).

[26] CNews has released a rating of Russian data centers. URL: https://www.cnews.ru/news/top/2020-04-

28_cnews_vypustil_rejting_rossijskih (accessed 02.10.2020).

[27] Russian commercial data center market: a look at the regions. URL: http://ekb.dcforum.ru/sites/default/files/9.35-9.50_-_iksconsulting_mirin_ekb-2019.pdf (accessed 02.10.2020).

[28] The Ministry of Communications of Russia will develop a rating of the attractiveness of regions for the construction of data centers. URL: https://digital.gov.ru/ru/events/39334/ (accessed 02.10.2020).

[29] I. Hala, Launch of the first regional 3data data centers under the franchise. $\mathrm{http} / / /$ dcregion.ru/sites/default/files/3data_regiony_v03_4x3.pdf (accessed 02.10.2020).

[30] S. Mirin, The Russian data centers market. Regions as a driver of development.

http://dcregion.ru/sites/default/files/skachat_prezentaciyu.pdf (accessed 09.10.2020). 